\title{
WNT7A Gene
}

National Cancer Institute

\section{Source}

National Cancer Institute. WNT7A Gene. NCI Thesaurus. Code C20099.

This gene plays a role in signal transduction and intercellular communication. It is involved in limb development. 